\section{Waiting for summer}

Chris Shermell reports on latest developments in Britain's nuclear power debate, now picking up again

THE issue continues to insinuate itself; only its locus changes. The excitement over nuclear power in recent weeks-since President Carter announced his policy-has been generated in various international forums, notably in London at the meeting of the so-called nuclear suppliers group and at the Downing Street economic summit, and in Salzburg, where two conferences were held in quick succession.

Now the issue is coming home. The second Salzburg conference had not even ended late last week before British experts were called away to attend one of the two meetings which took place in London at the weekend on domestic nuclear policy. The one bringing the experts back was called by $\mathrm{Mr}$ Anthony Wedgwood Benn, the UK Secretary of State for Energy, and was held in secret. Ironically, the other meeting, held in public and involving hundreds of largely lay people, attracted far less publicity. It was organised by Friends of the Earth (FoE).

Called a conference for a nonnuclear world, the FoE meeting produced a mostly young audience whose views on nuclear power were much as expected: negative. Their enthusiasm was fanned by remarks from two MPs, Robin Cook and Nigel Forman. Cook urged local groups to latch on to nuclear-related local issues and to exploit them relentlessly; Forman's advice was simple-citing a recent opinion poll, he said "secure yourself the help of a friendly scientist".

Neither man was invited to Benn's meeting, though the Commons was represented, through the chairman of the Select Committee on Science and Technology, Arthur Palmer. Indeed, many of the 30 or more people meeting in the seclusion of the Civil Service College at Sunningdale were favourably disposed to nuclear power. They included Sir John Hill of the UKAEA, Con Allday of BNFL, Ned Franklin of the National Nuclear Corporation (NNC), and Frank Tombs of the Electricity Council. Others present included Sir George Porter, Sir Alan Cottrell, Lord Todd, Sir Herman Bondi, Sir Kenneth Berrill, Lord Balogh, Dr Walter Marshall and Sir Brian Flowers - altogether a high-powered line-up.

That not all were so disposedWalter Patterson of FoE was there to put the alternative view-at least said something about Mr Benn's desire to hear all sides of opinion. And opinions were what he was there to hear: it was not a meeting to take decisions; rather, it was a meeting that anticipated them.

After months if not years of the public debate he has himself spurred on, $\mathrm{Mr}$ Benn is now coming under increasing pressure to call a halt to it all and to start, in the words of one participant at Sunningdale, doing what he was elected to do-take decisions. With the inquiry on an oxide fuel reprocessing plant at Windscale for BNFL due to begin on 14 June, that controversial issue is temporarily out of his hands. But two others await action.

One is on the choice of nuclear reactor for Britain, an issue which goes back to at least 1974, when everyone thought it was finally agreed that the Steam Generating Heavy Water Reactor (SGHWR) would be the country's next generation reactor. The issue was reopened last year, and decision-time has again arrived. The choice is between the SGHWR, the Advanced Gas-Cooled Reactor (AGR), a British product now apparently performing well after teething troubles, and the Pressurised Water Reactors (PWR) which now dominate the world market.

Press reports over the past couple of months have revealed a tilt in favour of the AGR. Mr Benn is himself awaiting a detailed report from the National Nuclear Corporation on the three types of reactor, and has advised its compilers of the sort of questions he wants answered. He is also awaiting a report from the National Nuclear Inspectorate on the safety of PWRs. Both reports are due out soon, probably next month.

At the weekend meeting Sir Brian Flowers, the former chairman of the Royal Commission whose report last year on nuclear power became the layman's locus classicus, urged that a choice be made. That report, the government's response to which is also due to be published shortly, escalated the debate on the fast breeder, which is the subject of $\mathrm{Mr}$ Benn's other decision. Having originally promised a decision last autumn and then stated earlier this year that a decision yet is not necessary, Mr Benn is now talking about the coming autumn as a deadline. The decision is on whether to go ahead with a demonstration commercial fast breeder (CFR1) at Dounreay, and the industry, notably in the form of Sir John Hill, is saying that there is no time to waste.

All the suggestions of urgency, and there are now many, do not derive from an immediate need for energy. The worry is that the growing surplus Britain is now acquiring will be lost by the $1990 \mathrm{~s}$, and that long lead times make action now essential if nuclear power is to play its allotted role alongside coal and conservation as one of the principal originators of Britain's supplies in the 1990s. That nuclear power is destined to do that was apparently agreed at Sunningdale; that it should entail a full nuclear cycle and

\title{
After Moscow, the world
}

EVERYONE knows the world market for energy has been transformed in this decade. Not everyone appreciates that the world market for energy (and every other commodity) could be transformed completely and even more radically within the next couple of decades if China and the USSR, separately or together, produce the sort of economic growth that countries like Japan or Germany have experienced.

One man who does claim to appreciate the problem is Britain's Secretary of State for Energy, Mr Anthony Wedgwood Benn. Last week he spent two full days in Moscow and came away enthralled. His purpose was to paint in the detail of the 'eastern perspective' on the global energy canvas that he likes to speak about. To get the other perspectives-west, north and south-he has already visited Washington, Norway and Saudi Arabia. Having assimilated all that, his next step will come at the EEC Council of Energy Ministers in the middle of June, when he reports back.

His tentative conclusion is that there is a need for a world energy policy.
What this means precisely is not clear: to many, a world policy implies a world government to implement it; to Mr Benn it means at the very least having information on world supply and demand for energy. He cites almost scornfully a book out this week on global energy prospects to the end of the century which takes no account of countries like China or the Soviet Union.

So what did he learn in Moscow? That the USSR is the world's biggest energy producer. That the Russians hope to use still higher voltage electricity transmission. That they are interested in Britain's offshore oil technology. That they do not dump medium-level nuclear waste into the sea. And that they are very keen to hear assessments of US nuclear policy.

Mr Benn also received one "small rebuke". Each year, he was told, 100 US scientists visited the USSR, and 100 from the USSR visited the States. For France the figure was 70. For Britain over a three-year period, however, the figure was only 50 .

Chris Sherwell 
a system of fast breeders was a matter of greater dispute.

From all accounts the participants agreed that if reprocessing was to be done at all, it could be done most reliably at Windscale. There was also fairly wide agreement that technically speaking enough could be done to combat the threat of proliferation, but that the problem of public acceptability -the all-important political dimension -would remain. Had any of the participants netained doubts on that score, the other weekend meeting might have helped to dispel them.

Now, with few new arguments to present or to hear, everyone with any influence over the shape of Britain's nuclear policy is hoping for just one thing: that with decisions ultimately a matter only of a signature, Mr Benn will have a restful summer.

\section{SWITZERLAND}

\section{Guidelines emerge}

Rosmarie Waldner reports from Zurich on Swiss moves to produce guidelines for genetic manipulation experiments

A Swiss Academy of Medical Sciences Committee founded in 1975, the Commission for Experimental Genetics, recently took the first step towards regulating genetic manipulation in Switzerland when it sent a circular to all researchers in the field of recombinant DNA recommending observance of the guidelines laid down by the US National Institutes of Health (NIH). Switzerland. It sent a circular to the guidelines issued for NIH researchers in June last year. The Swiss guidelines, however, are not legally binding, although they are considered to be obligatory for the researcher. The committee also wants research projects to be registered, in line with the recommendations of the Strasbourg-based European Science Foundation (ESF).

The commission, under the presidency of Professor Werner Arber of the Biozentrum of the University of Basle, is of the opinion that "things as they stand at present do not justify issuing an official order. The caution expected of researchers in this field, with its legal basis in the Epidemic Law, should ensure general observance of the recommended guidelines". The Swiss Epidemic Law regulates measures in connection with infectious diseases and is one of the few laws in the field of public health valid in all parts of Switzerland; public health, not being a federal matter, is under the jurisdiction of Switzerland's 25 cantons.

At their annual conference held in early April the Swiss Society for Cellular and Molecular Biology discussed the guidelines and voted overwhelmingly in favour in them. However, some speakers demanded that the guidelines be made legally binding and that the public should be brought into the discussion. Altogether six laboratories at the universities of Basle, Geneva and Zurich and at the im- munology institute of the pharmaceutical company Hoffman-La Roche in Basle are working with recombinant DNA.

The commission is available for advice or will arrange for expert assistance to be provided by the European Molecular Biology Organisation (EMBO) in Heidelberg if local researchers have any doubts about the correct classification of a research project within the various criteria of the $\mathrm{NIH}$ guidelines. It is also available for general consultation and for the interpretation of the NIH guidelines. As Professor Arber stresses, the commission does not consider the NIH guidelines adopted in Switzerland as unalterable; it wants to keep a constant watch and make changes (even if these deviated from the NIH guidelines) if this was considered necessary.

When registering, researchers responsible for a project must announce their intentions and state the precautionary measures taken. "The committee considers the observance of these measures, registration and the provision of correct information to colleagues to be part of the duty of each and every researcher", the circular states. Research heads and heads of department at universities and other public and private institutions have been requested to support the commission's efforts.

The Swiss National Fund for the Promotion of Scientific Research particularly wants to promote the research in Switzerland. When it comes to the allocation of research funds, however, it insists on observance of the guidelines. The fund has mentioned the possibility of becoming involved in the establishment of a special safety (P4) laboratory. This project is expected to cost SF1.5 million.

The Swiss press has welcomed the guidelines, but there have been complaints that decisions concerning research with such far-reaching consequences should have been made in camera-the commission has no lay representatives, nor even experts from
W. GERMANY

\section{Breeder hold-up}

UNDER increasing pressure from environmental protectionists, the West German government has called a temporary halt to research and development on the fast breeder reactor. Last week, Dr Hans Matthöfer, the West German Minister for Science and Technology, announced that no more money was to be spent on R\&D for the fast breeder until questions raised by the Social Democrats on the safety of fast breeder technology and the proliferation of nuclear weapons through the spread of plutonium had been considered by the Bundestag.

This means a bar on spending whatever has not yet been committed of the DM122 million set aside for fast breeder R\&D under the goverment's medium term energy plan. Work already contracted, however, such as the prototype liquid metal fast breeder at Kalkar, will go ahead. It will be financed from that portion of the DM227 million fast breeder programme not devoted to research. Other projects unlikely to be axed are West Germany's collaboration in the construction of the French Superphénix and the fabrication plant for fastbreeder fuel elements which is already in operation.

Prior to the latest announcement discussion about the further development of breeder reactors in West Germany was becoming livelier. In the Social Democratic party above all there was increasing resistance to further financing of R\&D work. The Ministry for Research and Technology had explained in detail to the Bundestag the pros and cons of the evolution of the fast breeder-it seems unsuccessfully.

Germany began development of the breeder in 1960 -researchers got their early experience through participation in the construction of the American experimental reactor SEFOR. The $300 \mathrm{MW}$ breeder at Kalkar is a German-Belgian-Dutch joint project due to be completed in 1982. Within the framework of the German-French agreement on Superphénix, Germany contributes $16 \%$ of the cost via electricity supply undertakings.

When the West German government presented its energy research programme at the end of April, Dr Matthöfer claimed that because of public resistance, his ministry had felt obliged not to balance the programme as much in favour of nuclear power as it had originally intended. It had been necessary to cut the target of $45,000 \mathrm{MW}$ of nuclear power by 1985 to $30,000 \mathrm{MW}$. Nevertheless, the energy research programme puts greatest emphasis on nuclear power: out of the DM6,200 million to be spent on energy up to 1980 , DM4,500 million was to go on nuclear energy.

fields other than biology and medicine. The hope was expressed that parliamentarians would soon be roused: questions were put in parliament as early as two years ago; since then there has been silence on the subject. 